\title{
Water Diffusion Coefficients of Selected Legumes Grown in Ghana as Affected by Temperature and Variety
}

\author{
Isaac Godfred Antwi*, Ahmad Addo, Ato Bart-Plange \\ Department of Agricultural and Biosystems Engineering, Kwame Nkrumah University of Science and Technology, Kumasi, \\ Ghana \\ Email: *yawantwi1966@gmail.com
}

How to cite this paper: Antwi, I.G., Addo, A. and Bart-Plange, A. (2021) Water Diffusion Coefficients of Selected Legumes Grown in Ghana as Affected by Temperature and Variety. Open Journal of Applied Sciences, 11, 861-873.

https://doi.org/10.4236/ojapps.2021.118063

Received: June 23, 2021

Accepted: August 9, 2021

Published: August 12, 2021

Copyright $\odot 2021$ by author(s) and Scientific Research Publishing Inc. This work is licensed under the Creative Commons Attribution International License (CC BY 4.0).

http://creativecommons.org/licenses/by/4.0/

\section{(c) (i) Open Access}

\begin{abstract}
The water absorption kinetics of cowpea and soybean hybrids were studied following the phenomenological models derived from Fick's diffusion law. Significant intra and inter varietal variations were observed on the physical characteristics of the seeds. The proposed Fick's law of diffusion was shown to significantly describe the kinetic of water absorption irrespective of the variety and temperature. The effective diffusivities of the hybrids were shown to vary in the order Nagbaar $>$ Nhyira $>$ Tonaa $>$ Anidaso and increased as the soaking temperature increased from $30^{\circ} \mathrm{C}$ to $60^{\circ} \mathrm{C}$. The estimated values for water diffusion coefficients varied from $2.90 \times 10^{-10}$ to $6.75 \times 10^{-10} \mathrm{~m}^{2} / \mathrm{s}$ for cowpea and soybean hybrids. An Arrhenius-type equation described the strong temperature effect on the diffusion coefficient with activation energies ranging from 7.73 to $8.56 \mathrm{~kJ} / \mathrm{mol}$ for cowpeas and 5.51 to $8.14 \mathrm{~kJ} / \mathrm{mol}$ for soybeans.
\end{abstract}

\section{Keywords}

Soybean, Cowpea, Water Absorption, Arrhenius-Type Equation, Diffusion Coefficient

\section{Introduction}

Legumes are important plant foods that are widely produced and consumed in many parts of Africa due to high amounts of protein and soluble fibre they contain. On dry weight basis, these foods contain mostly proteins $17 \%-28 \%$, fats $3.0 \%$, carbohydrates $50 \%-53 \%$, ash $3 \%$ and fibre $6 \%$ [1] [2] [3] [4]. Legumes also contain methionine which facilitates protein production in human beings 
[5]. Cowpea (Vigna unguiculata) and soybean (Glycine max) are among the different types of legumes grown across the continents of the world [6].

Generally, legumes often require a huge reduction in moisture content to ensure prolonged shelf life which would reduce or prevent deterioration in storage along the chain of distribution. However, seeds need to be hydrated first to facilitate processing operations such as milling, cooking or canning. In order to obtain better quality protein, it is necessary to reduce the cooking time, which can be achieved by soaking before cooking as reported by other researchers [7] Soaking of legume seeds prior to further processing is a common practice in the West African region. It induces moisture absorption by seeds, as influenced by soaking time and temperature of the soaking medium, thus, affecting the moisture content of the seeds. The moisture content of seeds influences the physical properties of the seeds [8]. Temperature, variety, kernel size, and time of exposure affect the rate at which moisture enters into kernels. Among these factors, temperature and variety have been shown to have the greatest effect. An increase in temperature results in an increase in the rate of moisture absorption [9]. Control of this process may be improved with better knowledge of the distribution and movement of moisture within the kernel.

In sorption process and equipment design, it is highly desirable and of practical importance to know how fast the absorption of water can be accomplished, how it will be affected by processing variables [10], and to predict the moisture gain by seeds as a function of time and temperature. This, however, depends on availability of moisture diffusivity data. Several hydration models such as the exponential model, the Peleg's model, first-order kinetics, Becker's model among others have been developed by various researchers to predict rehydration of several legume seeds. However, as of now the rehydration model for effects of processing variables on the rate of water uptake and moisture diffusivity in some existing legumes grown in Ghana such as Tona, Nhyira, Nagbaar and Anidaso varieties have not been clearly established. Thus, the research was carried out to study the influence of temperature and variety on the water absorption characteristics of these newly developed seeds of soybean and cowpea varieties.

\section{Material and Methods}

\subsection{Preparation of Samples}

Samples of two hybrids of cowpea (Tona and Nhyira) and two hybrids of soybean (Nagbaar and Anidaso) were obtained from the experimental farm of the Council for Scientific and Industrial Research-Crops Research Institute (CSIR-CRI) at Fumesua, Kumasi. The samples were husked manually. Only good grains were weighed and used for the experiment. The samples of each variety were separately packed into air-tight polythene bags and stored at $4^{\circ} \mathrm{C}$ to prevent moisture loss and recontamination.

\subsection{Determination of Moisture Content}

The initial moisture content of each variety sample was determined using the 
standard oven drying method according to [11] and expressed as $\mathrm{kg} / \mathrm{kg}$ (dry basis). Five samples of $5 \mathrm{~g}$ were weighed to an accuracy of $0.01 \mathrm{~g}$ and placed in numbered dishes. The dishes were placed in standard oven and uniformly heated for $4 \mathrm{~h}$ to temperature of $103^{\circ} \mathrm{C} \pm 2^{\circ} \mathrm{C}$. The procedure was replicated three times for each sample, and the average value was taken and recorded.

\subsubsection{Determination of the Physical Characteristics}

The physical characteristics of the legume's kernels were evaluated essentially according to [12] with minor modifications where necessary. For each grain sample, 100 grains were selected at random and the principal dimensions of the kernels were measured in three directions using a digital micrometer screw gauge with accuracy of $0.01 \mathrm{~mm}$. The major diameter is the length of the kernel, the intermediate diameter is the width, and the minor diameter is the thickness of the kernel. The minor diameter is taken perpendicular to the intermediate diameter. The micrometer screw gauge was held perpendicular to the direction of the dimension being measured. Length was measured on 100 kernels and width and thickness on 50 kernels [13] and average value was determined for each sample. Owning to the irregular or non-uniform nature of the shape of the kernels, the greatest value of both the width and the thickness were taken.

\subsubsection{Determination of Equivalent Radius}

The average equivalent radius was calculated for 50 seeds. This was based on the assumption that the volume of the kernel can be approximated by calculating the volume of a sphere with radius equal to half diameters of the kernel.

The volume of the kernel was determined by filling a $100 \mathrm{ml}$ measuring cylinder with $50 \mathrm{ml}$ of water. Then, 50 kernels of each variety (separately) were immersed in the water. The amount of displacement in water was recorded. The procedure is replicated three times and true volume was calculated.

Average volume of the kernel was equated to the volume of a spherical object (i.e. $V=\frac{4}{3} \pi r^{3}$ ) and equivalent radius $\mathrm{R}$ was obtained.

Thus,

$$
R=\sqrt[3]{\frac{3 v}{4 \pi}}
$$

\subsection{Soaking Experiment}

Samples were soaked at four different water temperatures of $30^{\circ} \mathrm{C} \pm 2^{\circ} \mathrm{C}, 40^{\circ} \mathrm{C} \pm$ $2^{\circ} \mathrm{C}, 50^{\circ} \mathrm{C} \pm 2^{\circ} \mathrm{C}$, and $60^{\circ} \mathrm{C} \pm 2^{\circ} \mathrm{C}$ in a thermostatic water bath. Three replicates of sample size $50.02 \mathrm{~g}$ each sample was separately placed in nylon mosquitoe net, tied and labelled before they were placed into the portable water bath. The cowpea samples were removed at predetermined time interval of $60 \mathrm{~min}$. Thereafter, measurements were carried out at $30 \mathrm{~min}$ for the soybean hybrids. The soaked samples were quickly blotted with tissue paper to remove residual surface moisture on the surface of the kernels [14] and then reweighed [15] [16]. At each interval, the water content of the seeds was calculated as the difference between the weight of the dry solids and soaked seeds. The saturation moisture content $\left(\mathrm{M}_{\mathrm{s}}\right)$ 
was determined when the subsequent increase in weight of soaked grain was less than $0.01 \mathrm{~g}$.

\subsection{Modelling of Rehydration Kinetics}

During a diffusion process at constant temperature, it is assumed that the process follows Fick's second law of diffusion. For an axisymmetric diffusion, Fick's three-dimensional (3D) equation was given by:

$$
\frac{\partial M}{\partial t}=D\left(\frac{\partial^{2} M}{\partial x^{2}}+\frac{\partial^{2} M}{\partial y^{2}}+\frac{\partial^{2} M}{\partial z^{2}}\right)
$$

where, $M$ is the instantaneous moisture content at a specified time $t$ and $D$ is the diffusion coefficient. A solution for the above equation for an object with a sphere shape of radius $r$ was presented by [14] and [17], as

$$
M R=\frac{M-M_{i}}{M_{e}-M_{i}}=1-\left(\frac{6}{\pi^{2}}\right) \sum_{i=1}^{\infty}\left(\frac{1}{i^{2}}\right) \exp \left(-D i^{2} \pi^{2} \frac{t}{r^{2}}\right)
$$

where, $M R$ is the moisture ratio, and $M_{i}$ and $M_{e}$ are, respectively, the initial and the equilibrium moisture contents, $i$ is the number of terms in summation (equal to 1000 in this study), $D i$ is the effective water diffusion coefficient, and $r$ is the characteristic length of the seed (equal to radius for sphere of the same volume as the volume of the kernels) and $t$ is the soaking time. In this case, only a finite number of Equation (3) was used for estimating $M R$ values. All moisture terms were computed on dry basis.

In this research, the experimental $M R$ values at specific time intervals were calculated and used as input to the curve fitting tool box of Microsoft Excel, 2010 software and the diffusion coefficient of the selected cereals and legumes, $D i$ were estimated.

Temperature dependency of $D i$ was described by an Arrhenius type equation [18]:

$$
D i=D_{o} \mathrm{e}^{-E / R T}
$$

where:

$D_{o}\left(\mathrm{~m}^{2} / \mathrm{s}\right)$ is diffusion constant,

$E(\mathrm{~kJ} / \mathrm{mol})$ the activation energy,

$R(8.314 \mathrm{~J} / \mathrm{mol} \mathrm{K})$ the gas constant,

$T(\mathrm{~K})$ the absolute temperature.

Activation energy values were obtained from the linear regression ( $D i$ vs. 1/T) analysis. The diffusion constant $\left(D_{o}\right)$ and the slope $(E / R)$ in the equation were determined using the least squares method. The value of the energy of activation (Ea) was determined by multiplying the value of the slope by the gas constant value.

\section{Results and Discussion}

\subsection{Physical Properties}

Initial moisture contents, dimensions, and radius of each kernel of the legumes 
studied in this work are given in Table 1.

The data presented in Table 1 are in general agreement with those reported by other researchers. [19] reported on cowpea seeds the range values of $\mathrm{L}, \mathrm{W}$ and $\mathrm{T}$, to be $0.73-0.92 \mathrm{~cm}, 0.55-0.73 \mathrm{~cm}$ and $0.38-0.58 \mathrm{~cm}$, respectively; while the values reported by [20] and [21] on cowpea for $\mathrm{L}, \mathrm{W}$ and $\mathrm{T}$, are $0.73-1.00 \mathrm{~cm}$, $0.49-0.73 \mathrm{~cm}$ and $0.33-0.57 \mathrm{~cm}$, respectively.

From Table 1, the surface area (SA) ranged from $307.59 \mathrm{~mm}^{2}$ (Nhyira) to $379.35 \mathrm{~mm}^{2}$ (Nagbaar). While no significant difference was observed in the (SA) of the soybean hybrids, Tona was observed to be higher than Nhyira in the case of cowpea hybrids. In general, for different cultivars of legume, one can expect an inverse relation between the rate of water absorption and seed size, since a larger seed provides a smaller surface area per unit mass (specific surface area) for moisture transfer [22]. Physical and colour characteristics of cowpea and soybean seeds revealed a difference between the two legumes species, but not much differences existed amongst individual hybrids, which could probably influence their differences to absorb water.

\subsection{Saturation Moisture Content and Diffusion Coefficient}

The observed saturated moisture contents of the grains were shown to vary with the variety and the temperature (Table 2). The hybrid with high saturation moisture was Tona with mean water absorption of $143.9 \mathrm{~g}$ water $/ 1000 \mathrm{~g}$ dry weight followed by Nhyira hybrid with a mean water absorption of $110.4 \mathrm{~g}$ water/1000g dry weight. Studies by [19] and [20] reported similar range values of

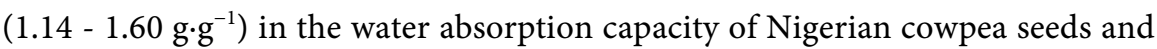
$\left(1.14-1.60 \mathrm{~g} \cdot \mathrm{g}^{-1}\right)$ in Cameroun cowpeas respectively. This result also confirms

Table 1. Moisture content and physical properties of legume hybrids.

\begin{tabular}{ccccccc}
\hline Legume & $\begin{array}{c}\text { Moisture content } \\
(\% \mathrm{db})\end{array}$ & $\begin{array}{c}\text { Length } \\
(\mathrm{mm})\end{array}$ & $\begin{array}{c}\text { Width } \\
(\mathrm{mm})\end{array}$ & $\begin{array}{c}\text { Thickness } \\
(\mathrm{mm})\end{array}$ & $\begin{array}{c}\text { Radius } \\
(\mathrm{mm})\end{array}$ & $\begin{array}{c}\text { Surface Area } \\
\left(\mathrm{mm}^{2}\right)\end{array}$ \\
\hline Tona & 10.9 & 7.55 & 5.79 & 4.52 & 3.24 & 335.08 \\
Nhyira & 10.4 & 6.95 & 5.75 & 4.39 & 3.04 & 309.54 \\
Nagbaar & 10.4 & 7.53 & 6.21 & 5.09 & 3.42 & 379.35 \\
Anidaso & 9.9 & 7.74 & 5.98 & 5.09 & 3.33 & 376.77 \\
\hline
\end{tabular}

Table 2. Saturation moisture contents and diffusion coefficients of selected local legumes.

\begin{tabular}{cccccccccccccc}
\hline $\mathrm{T} /{ }^{\circ} \mathrm{C}$ & \multicolumn{3}{c}{30} & \multicolumn{3}{c}{40} & \multicolumn{3}{c}{50} & & & 60 \\
\hline Legumes & $\mathrm{D}_{\mathrm{i}}^{*}$ & $\mathrm{R}^{2}$ & $\mathrm{Ms}$ & $\mathrm{D}_{\mathrm{i}}^{*}$ & $\mathrm{R}^{2}$ & $\mathrm{Ms}$ & $\mathrm{D}_{\mathrm{i}}^{*}$ & $\mathrm{R}^{2}$ & $\mathrm{Ms}$ & $\mathrm{D}_{\mathrm{i}}^{*}$ & $\mathrm{R}^{2}$ & $\mathrm{Ms}$ \\
\hline Tona & 4.36 & 0.88 & 124.5 & 4.54 & 0.93 & 128.0 & 5.12 & 0.94 & 132.8 & 5.90 & 0.99 & 143.9 \\
Nhyira & 4.74 & 0.99 & 97.6 & 5.38 & 0.98 & 102.8 & 5.79 & 0.96 & 106.2 & 6.28 & 0.87 & 110.4 \\
Nagbaar & 5.05 & 0.97 & 140.2 & 5.81 & 0.96 & 141.1 & 6.39 & 0.95 & 142.7 & 6.75 & 0.86 & 143.0 \\
Anidso & 2.90 & 0.99 & 118.0 & 3.12 & 0.96 & 124.0 & 3.25 & 0.92 & 126.2 & 3.56 & 0.92 & 128.7 \\
\hline$* 10^{-10} \mathrm{~m}^{2} / \mathrm{s}$. & & & & & & & & & & & &
\end{tabular}


[21] assertion, that attributed high water absorption by cowpea seeds to larger seed size because Tona hybrid which is bigger possessed the higher saturation moisture content. This observation is in contrast to earlier reports by [23] and [24] that the smaller a seed is, the larger is its water absorption capacity. The soybean had similar water absorption as shown by their respective maximum moisture content of $143.0 \mathrm{~g}$ water/1000g dry weight for Nagbaar and $128.7 \mathrm{~g}$ water/1000g dry weight for Anidaso. Also, Nagbaar and Anidaso have similar seed size yet their degree of moisture gain was quite different. The differences observed on the saturation moisture content clearly highlighted the differences between species and varieties. However, it appears, the size of kernel is not a dominant factor that influences water absorption capacity of legumes. This confirms earlier reports by [7] and [25]. Figures 1-4 show the time variation in water absorption by Tona, Nhyira, Nagbaar and Anidaso at different temperatures.

The variation of the effective diffusivity of the different seed varieties with temperature is shown in Table 2. Equation (3) was used to estimate the diffusion coefficients of the legume hybrids during water absorption. The SMCs used in Equation (3) and diffusion coefficients for water absorption are listed in Table 2. The water absorption rates for Tona, Nhyira, Nagbaar and Anidaso are shown in Figures 5-8 respectively.

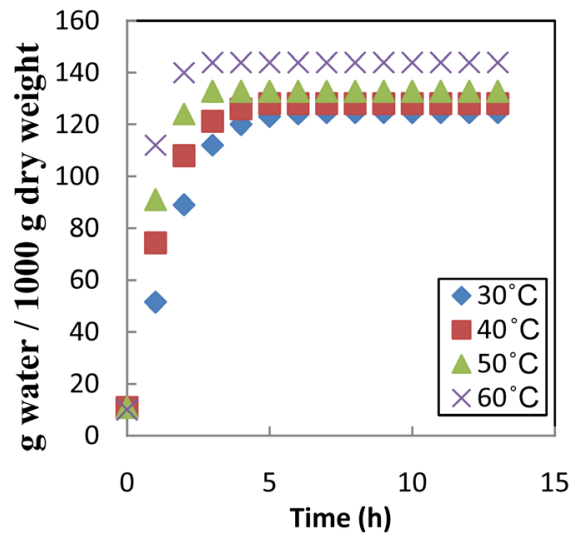

Figure 1. Water absorption characteristics of Tona.

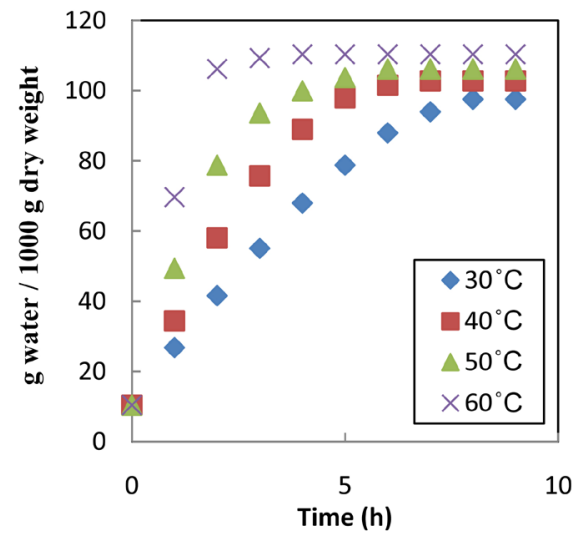

Figure 2. Water absorption characteristics of Nhyira. 


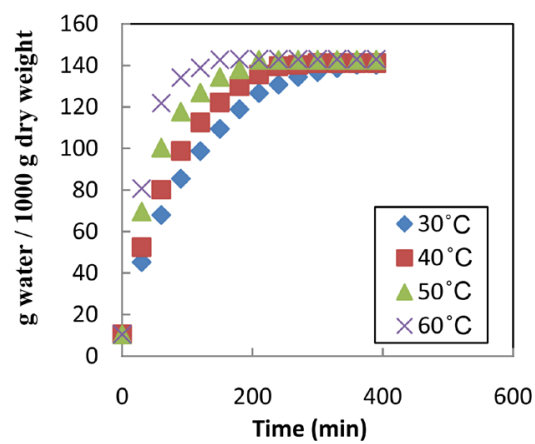

Figure 3. Water absorption characteristics of Nagbaar.

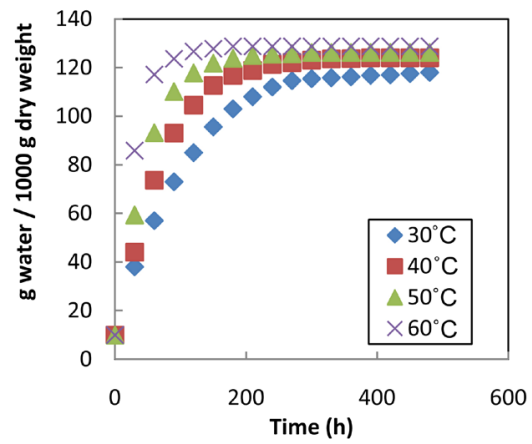

Figure 4. Water absorption characteristics of Anidaso.

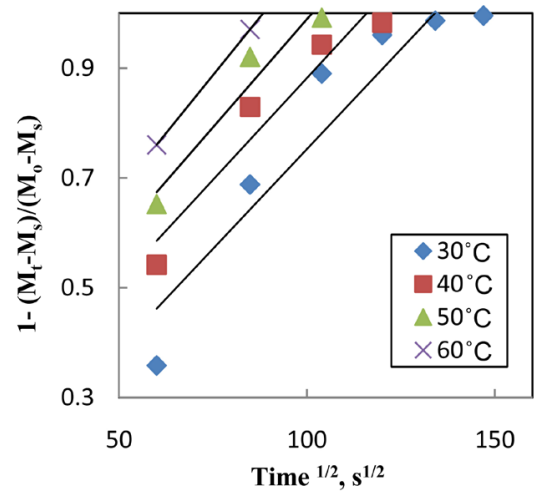

Figure 5. Water absorption rate for Tona.

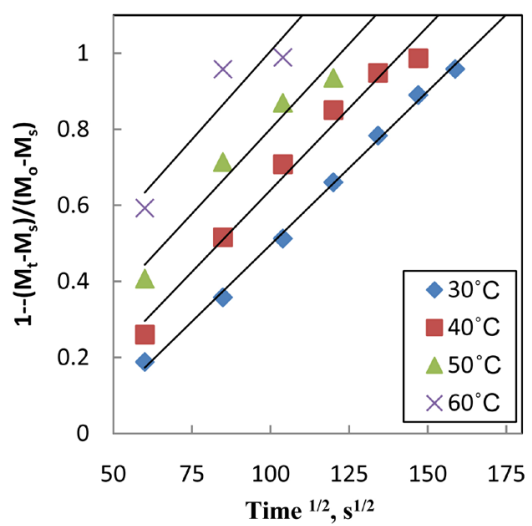

Figure 6. Water absorption rate for Nhyira. 


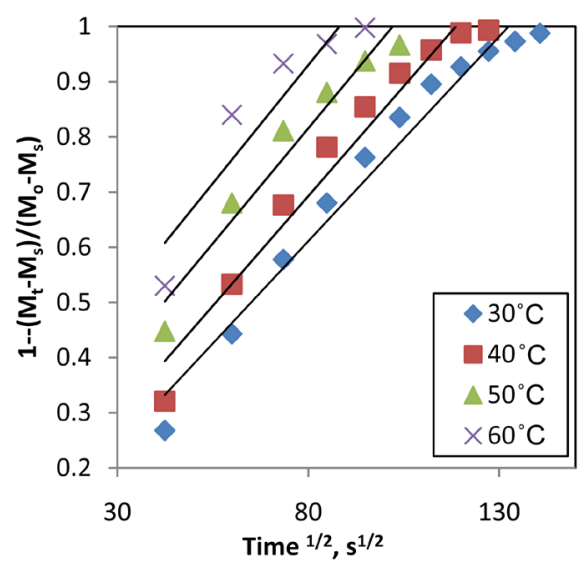

Figure 7. Water absorption rate for Nagbaar.

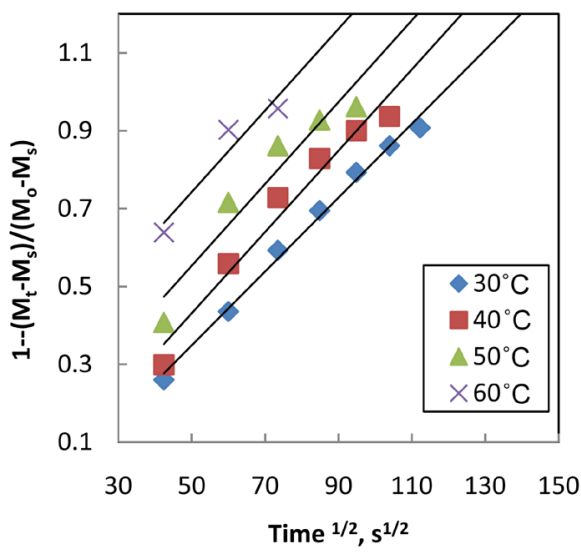

Figure 8. Water absorption rate for Anidaso.

From Table 2, it is possible to verify the increase in effective diffusivity when temperature is raised. The diffusivities of the seeds were shown to vary in the order Nagbaar $>$ Nhyria $>$ Tona $>$ Anidaso and increased as the soaking temperature increased from $30^{\circ} \mathrm{C}$ to $60^{\circ} \mathrm{C}$. The variation in the effective diffusivity at $30^{\circ} \mathrm{C}$ and $60^{\circ} \mathrm{C}$ was observed to be linearly correlated ( $\mathrm{R} 2>0.86$ ). Diffusion coefficient values were 2.90 to $3.56 \times 10^{-10} \mathrm{~m}^{2} / \mathrm{s} ; 4.36$ to $5.90 \times 10^{-10} \mathrm{~m}^{2} / \mathrm{s} ; 4.74$ to $6.28 \times 10^{-10} \mathrm{~m}^{2} / \mathrm{s}$; and 5.05 to $6.75 \times 10^{-10} \mathrm{~m}^{2} / \mathrm{s}$ for Anidaso, Tona; Nhyira and Nagbaar respectively. The differences observed in the diffusion coefficient values for Nhyira and Tona could be as a result of the variations in their seed characteristics since they are different varieties of cowpea [26]. According to [27], proteins and carbohydrates are the two main constituents of seeds, which have the ability to absorb so much water, with proteins having a higher water absorption power than carbohydrates. Thus, the differences in the nutritional compositions of Nhyira and Tona cowpea seeds could also be another reason for the diffusion coefficient values of Tona cowpea seeds being higher than that of Nhyira cowpea variety. It is therefore possible that Nhyira cowpea seeds have higher protein content than that of Tona, making Nhyira cowpea seeds absorb more water than the Tona cowpea varieties under the same temperature treatments and the same 
soaking time. Also, Nhyira with smaller surface area recorded higher diffusion coefficient than Tona as expected. A similar observation has also been reported for soybean varieties [22]. On the other hand, Nagbaar variety recorded the higher diffusion coefficient than Anidaso even though their surface areas (seed size) are almost the same. [28] calculated higher water absorption rates for large-seed (i.e. smaller SSA) cultivars of chickpeas. It is important to note that Nagbaar and Anidaso of the soybean variety have similar surface area, however, there was large difference in their diffusion coefficients as shown in Table 2. Therefore, the relation between diffusion coefficient and surface area appears to be valid only for some legumes (cowpea) rather than being a general rule for all legumes. Moreover, surface area seems to be one of several factors controlling the rate of water absorption in legumes but not a dominant one (e.g. soybean). This implies that other factors might have contribution toward the slower rate observed for Anidaso hybrid.

Since there was no published report on absorption characteristics of soybean variety grown in Ghana, direct comparison of the results of this study cannot be provided. However, diffusivity values reported in this study were lower than those obtained by [27] for egusi melon seed. On the other hand, these values compared favourably with other published values of $3.96 \times 10^{-10}$ to $6.64 \times 10^{-10}$ $\mathrm{m}^{2} / \mathrm{s}$ by [29] and $2.16 \times 10^{-10}$ to $1.19 \times 10^{-9} \mathrm{~m}^{2} / \mathrm{s}$ by [19]. In addition, it can be noted that changes of the diffusivity with temperature suggest that parameters such as the thermal properties of the seeds may be important factors in water diffusivity of seeds in addition to other varietals parameters.

The values of diffusion coefficients of the selected varieties were fitted to an Arrhenius relationship (Equation (4)). The Arrhenius equation was sufficient to describe the temperature effect on the moisture diffusivity of the selected varieties as the coefficient of determination $\left(\mathrm{R}^{2}\right)$ of fitting was between 0.93 and 0.98 (Table 3). The relationship between the diffusion coefficients and the reciprocal of the absolute temperatures is shown in Figure 9.

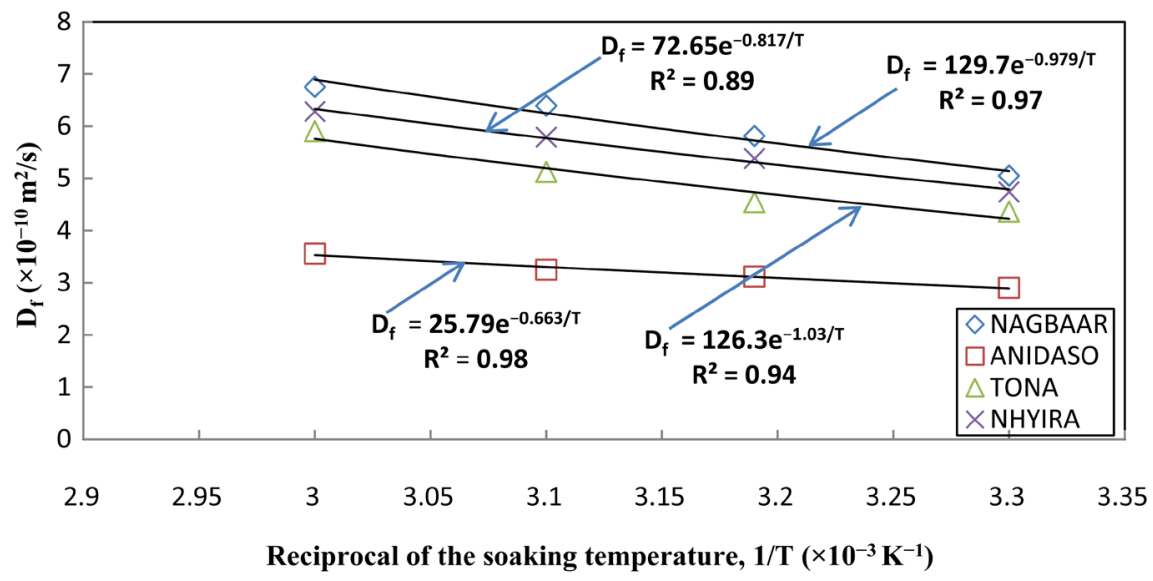

Figure 9. Relationship between diffusion coefficient and temperature for legume (Tona, Nhyira, Anidaso and Nagbaar). 
Table 3. Activation energy of water diffusion during soaking of selected dry legumes grown in Ghana.

\begin{tabular}{ccc}
\hline Legume & $\mathrm{Ea}(\mathrm{kJ} / \mathrm{mol})$ & Regression coefficient $\left(\mathbf{R}^{2}\right)$ \\
\hline Soybean & & 0.97 \\
Nagbaar & 8.14 & 0.98 \\
Anidaso & 5.51 & \\
Cowpea & & 0.94 \\
Tona & 8.56 & 0.89 \\
\hline Nhyira & 7.73 & \\
\hline
\end{tabular}

Figure 9 shows the Arrhenius relation for the diffusion coefficients and temperature of Anidaso, Hhyira, Tona and Nagbaar. The variation of moisture diffusivity with the soaking temperature was consistent with the observations of [28] and [29] for the beans, peas, soybeans and the cultivars of chickpeas. The activation energy values for water diffusion in the legumes were also presented in Table 3.

From Table 3, the temperature sensitivity of Di was highest for Nagbaar with activation energy being $8.14 \mathrm{~kJ} / \mathrm{mol}$ and lowest for Anidaso with activation energy being $5.51 \mathrm{~kJ} / \mathrm{mol}$. The activation energy values obtained in this study for soybean varieties were quite smaller than $44.3 \mathrm{~kJ} / \mathrm{mol}$ for soybean and 51.4 $\mathrm{kJ} / \mathrm{mol}$ for pigeon pea as reported by [14] and [30] respectively. However, the value obtained for soybean was close to the $11.20 \mathrm{KJ} / \mathrm{mol}$ reported by [28] for white Bambara groundnut. The activation energy is a function of the grain composition therefore variations in seed characteristics may account for the differences in the activation energies. The lower value of activation energy could also mean that the seeds were more thermally stable. [31], made similar observation when they studied Kinetic, thermodynamic properties, and optimization of barley hydration. The work showed significantly lower values of activation energy for varieties of barley.

The values of activation energy obtained for the two cowpea varieties were similar to those reported by [18] and [29].

\section{Conclusion}

The water absorption kinetics of two cowpea varieties (Tona and Nhyira) and two soybean varieties (Nagbaar and Anidaso) were studied following the phenomenological models derived from Fick's law of diffusion. Hydration temperature, time and variety had a significant influence on the hydration kinetics of legumes. Surface area seems to be one of several factors controlling the rate of water absorption in legumes. However, this is valid only for some legumes rather than being a general rule. The simple Fick's diffusion equation successfully simulated the water absorption kinetics of the soybean and cowpea hybrids at all temperatures. The effective water diffusivity values for Tona, Nhyira, Nagbaar and Anidaso varied from $4.36 \times 10^{-10} \mathrm{~m}^{2} / \mathrm{s}$ to $5.90 \times 10^{-10} \mathrm{~m}^{2} / \mathrm{s}, 4.74 \times 10^{-10} \mathrm{~m}^{2} / \mathrm{s}$ 
to $6.28 \times 10^{-10} \mathrm{~m}^{2} / \mathrm{s}, 5.05 \times 10^{-10} \mathrm{~m}^{2} / \mathrm{s}$ to $6.75 \times 10^{-10} \mathrm{~m}^{2} / \mathrm{s}$ and $2.90 \times 10^{-10} \mathrm{~m}^{2} / \mathrm{s}$ to $3.56 \times 10^{-10} \mathrm{~m}^{2} / \mathrm{s}$ respectively. Parameters such as thermal properties of the seeds may be important factors in water diffusivity of seeds in addition to other varietals parameters. The intense influence of temperature on the water diffusion coefficient was adequately described by an Arrhenius-type equation giving activation energy values of Tona, Nhyira, Nagbaar and Anidaso as $8.56 \mathrm{~kJ} / \mathrm{mol}, 7.73$ $\mathrm{kJ} / \mathrm{mol}, 8.14$ and $5.51 \mathrm{~kJ} / \mathrm{mol}$, respectively.

\section{Acknowledgements}

The authors express their appreciation to the CSIR-Crops Research Institute (CSIR-CRI) at Fumesua, Kumasi Ghana and the Agricultural and Biosystems Engineering Department of KNUST, Kumasi Ghana.

\section{Funding}

This research did not receive any specific grant from funding agencies in the public, commercial or not-for-profit sectors.

\section{Conflicts of Interest}

The authors declare that there is no conflict of interest regarding the publication of this paper.

\section{References}

[1] Davies, R.M. and Zibokere, D.S. (2011) Effect of Moisture Content on Some Physical and Mechanical Properties of Three Varieties of Cowpea (Vigna unguiculata (L) Walp). Agricultural Engineering International: CIGR Journal, 13, 1-16. http://www.cigrjournal.org/index.php/Ejounral/article/viewFile/1700/1397

[2] Mbofung, C.M.F., Njintang, Y.N. and Waldrom, K.W. (2002) Functional Properties of Cowpea-Soy-Dry Red Beans Composite Four Paste and Sensorial Characteristics of Akara (Deep Fat Fried Food): Effect of Whipping Conditions, pH, Temperature and Salt Concentration. Journal of Food Engineering, 54, 207-214. https://doi.org/10.1016/S0260-8774(01)00196-0

[3] Mbofung, C.M.F., Rigby, N. and Waldrom, K. (1999) Use of Two Varieties of Hard-to-Cook-Beans (Phaseolus vulgaris) and Cowpea (Vigna unguiculata) in the Processing of Koki (a Steamed Legume Product). Plant Foods for Human Nutrition, 54, 131-150. https://doi.org/10.1023/A:1008169000428

[4] Phillips, R.D., McWatters, K.H., Chinnan, M.S., Hung, Y.C., Beuchat, L.R. and Sefa-Dedeh, S. (2003) Utilization of Cowpeas for Human Food. Field Crops Research, 82, 193-213. https://doi.org/10.1016/S0378-4290(03)00038-8

[5] Shafaei, S.M., Masoumi, A.A. and Roshan, H. (2016) Analysis of Water Absorption of Bean and Chickpea during Soaking Using Peleg Model. Journal of the Saudi Society of Agricultural Sciences, 15, 135-144. https://doi.org/10.1016/j.jssas.2014.08.003

[6] Firouzi, S. and Alizadeh, M. (2012) Effect of Moisture Content on Selected Physical Characteristics of Cowpea Seed (Vigna unguiculata L. Walp). Annals of Biological Research, 3, 3583-3590.

[7] Wang, L., Swain, C.W., Hesseltine, C.W. and Heath, H.D. (1979) Hydration of 
Whole Soybeans Affects Solids Losses and Cooking Quality. Journal of Food Science, 44, 1510-1513. https://doi.org/10.1111/j.1365-2621.1979.tb06474.x

[8] Zubairu, U.B., Aimrun, W. and Amin, M.S.M. (2014) Determination of Some Physical Properties of Common Malaysian Rice MR219 Seeds. Australian Journal of Crop Science, 8, 332-337

[9] Kashaninejadl, M. and Kashiri, M. (2007) Hydration Kinetics and Changes in Some Physical Properties of Wheat Kernels. Journal of Iranian Food Science and Technology Research, 45, 58-59.

[10] Verma, R.C. and Prasad, S. (1999) Kinetics of Absorption of Water by Maize Grains. Journal of Food Engineering, 39, 395-400.

https://doi.org/10.1016/S0260-8774(99)00027-8

[11] (1988). ASAE S352.2 APR1988 (R2012) Moisture Measurement-Unground Grain and Seeds.

https://www.yumpu.com/en/document/read/33351839/annual-report-americansoci ety-of-agricultural-and-biological

[12] Baryeh, E.A. (2001) Physical Properties of Bambara Groundnuts. Journal of Food Engineering, 47, 321-326. https://doi.org/10.1016/S0260-8774(00)00136-9

[13] Hauhouot-O’Hare, M., Criner, B.R., Brusewitz, G.H. and Solie, J.B. (2000) Selected Physical Characteristics and Aerodynamic Properties of Cheat Seed for Separation from Wheat. CIGR Journal of Scientific Research and Development, 2, 347-356.

[14] Seyhan-Gurtas, F., Ak, M.M. and Evranuz, E.O. (2001) Water Diffusion Coefficients of Selected Legumes Grown in Turkey as Affected by Temperature and Variety. Turkish Journal of Agriculture, 25, 297-304.

[15] Fan, L.T., Chu, P.S. and Shellenberger, J.A. (1963) Diffusion of Water in Kernels of Corn and Sorghum. Cereal Chemistry, 40, 303-313.

[16] Lu, R., Siebenmorgen, T.J. and Archer, T.R. (1994) Absorption of Water in Long-Grain Rough Rice during Soaking. Journal of Food Process Engineering, 17, 141-154. https://doi.org/10.1111/j.1745-4530.1994.tb00332.x

[17] Crank, J. (1975) The Mathematics of Diffusion. Clarendon Press, Oxford, 47-49, 90-91.

[18] Addo, A. and Bart-Plange, A. (2009) Kinetics of Water Sorption by Egusi Melon (Cucumeropsis edulis) Seeds. ARPN Journal of Agricultural and Biological Science, 4, 14-17.

[19] Kaptso, K.G., Njintang, Y.N., Komnek, A.E., Hounhouigan, J., Scher, J. and Mbofung, C.M.F. (2008) Physical Properties and Rehydration Kinetics of Two Varieties of Cowpea (Vigna unguiculata) and Bambara Groundnuts (Voandzeia subterranea) Seeds. Journal of Food Engineering, 86, 91-99.

https://doi.org/10.1016/j.jfoodeng.2007.09.014

[20] Olapade, A.A., Okafor, G.I., Ozumba, A.U. and Olatunji, O. (2002) Characterization of Common Nigerian Cowpea (Vigna unguiculata L. Walp) Varieties. Journal of Food Engineering, 55, 101-105. https://doi.org/10.1016/S0260-8774(02)00022-5

[21] Taiwo, K.A. (1998) The Potential of Cowpea as Human Food in Nigeria. Technovation, 18, 469-481. https://doi.org/10.1016/S0166-4972(98)00015-7

[22] Hsu, K.H. (1983) A Diffusion Model with a Concentration-Dependent Diffusion Coefficient for Describing Water Movement in Legumes During Soaking. Journal of Food Science, 48, 618-622. https://doi.org/10.1111/j.1365-2621.1983.tb10803.x

[23] Sopade, P.A. and Obekpa, J.A. (1990) Modelling Water-Absorption in Soybean, Cowpea and Peanuts at Three Temperatures Using Peleg Equation. Journal of Food 
Science, 55, 1084-1087. https://doi.org/10.1111/j.1365-2621.1990.tb01604.x

[24] Tang, J., Sokhansanj, S. and Sosulski, F.W. (1994) Moisture-Absorption Characteristics of Laird Lentils and Hard-Shell Seeds. Cereal Chemistry, 71, 423-428.

[25] Chopra, R. and Prasad, D.N. (1994) Standardization of Soaking Conditions for Soybean Seeds Cotyledons for Improved Quality of Soymilk. Indian Journal of Animal Science, 64, 405-410.

[26] Haros, M., Viollaz, P.E. and Suarez, C. (1995) Effect of Temperature and $\mathrm{SO}_{2}$ on the Rates of Water Absorption of Three Maize Hybrids. Journal of Food Engineering, 25, 473-482. https://doi.org/10.1016/0260-8774(94)00022-2

[27] Agarry, S.E., Afolabi, T.J. and Akintunde, T.T.Y. (2014) Modelling the Water Absorption Characteristics of Different Maize (Zea Mays L.). Types during Soaking. Journal of Food Processing \& Technology, 5, Article No. 326. https://doi.org/10.4172/2157-7110.1000326

[28] Hung, T.V., Liu, L.H., Black, R.G. and Trewhella, M.A. (1993) Water Absorption in Chickpea ( $C$. arietinum) and. Eld Pea ( $P$. sativum) Cultivars Using the Peleg Model. Journal of Food Science, 58, 848-852. https://doi.org/10.1111/j.1365-2621.1993.tb09374.x

[29] Idun-Acquah, N.N., Addo, A. and Bart-Plange, A. (2019) Effect of Soaking Temperature on Water Absorption Characteristics of Selected Ghanaian Cowpea Varieties. Open Journal of Applied Sciences, 9, 736-748.

https://www.scirp.org/journal/ojapps https://doi.org/10.4236/ojapps.2019.99060

[30] Singh, B.P. and Kulshrestha, S.P. (1987) Kinetics of Water Sorption by Soybean and Pigeon Pea Grains. Journal of Food Science, 52, 1538-1541. https://doi.org/10.1111/j.1365-2621.1987.tb05874.x

[31] Montanuci, F.D., Matos Jorge, L.M. and Matos Jorge, R.M. (2013) Kinetic, Thermodynamic Properties, and Optimization of Barley Hydration. Food Science and Technology, 33, 690-698. https://doi.org/10.1590/S0101-20612013000400014 